\title{
Structures of LDHs Intercalated with Ammonia and the Thermal Stability for Poly(vinyl chloride)
}

\author{
Xiaoyu Xue, Shuhua Zhang*, Hongmei Zhang \\ College of Chemistry and Chemical Engineering, Shanghai University of Engineering Science, Shanghai, China \\ Email: $635749308 @ q q . c o m$
}

Received 5 February 2015; accepted 13 March 2015; published 17 March 2015

Copyright (C) 2015 by authors and Scientific Research Publishing Inc.

This work is licensed under the Creative Commons Attribution International License (CC BY).

http://creativecommons.org/licenses/by/4.0/

(c) (i) Open Access

\begin{abstract}
MgAl- $\mathrm{NH}_{3}$ LDHs (layered double hydroxides), $\mathrm{ZnAl}-\mathrm{LDHs}$ and $\mathrm{ZnAl}-\mathrm{NH}_{3}$ LDHs with different molar ratio of $\mathrm{Al} /$ ammonia were synthesized by co-precipitation method. The synthetic LDHs samples were characterized by XRD, FT-IR, TGA-DTG and SEM techniques and tested by Congo red method. In addition, after PVC (Poly vinyl chloride) and DOP (Dioctylphthalate) were added to LDHs, the thermal stability for PVC was characterized by TGA-DTG. The results indicated that LDHs intercalated with ammonia improved thermal stability for PVC significantly, $\mathrm{MgAl}-\mathrm{NH}_{3} \mathrm{LDHs}\left(\mathrm{Mg}^{2+}: \mathrm{Al}^{3+}\right.$ : $\left.\mathrm{NH}_{3} \cdot \mathrm{H}_{2} \mathrm{O}=3: 1: 0.5\right)$ and $\mathrm{ZnAl}-\mathrm{NH}_{3} \mathrm{LDHs}\left(\mathrm{Zn}^{2+}: \mathrm{Al}^{3+}: \mathrm{NH}_{3} \cdot \mathrm{H}_{2} \mathrm{O}=2: 1: 1.5\right)$ showed the best thermal stability for PVC, interlayered space of LDHs became larger by intercalating ammonia.
\end{abstract}

\section{Keywords}

Ammonia, Layered Double Hydroxide, Poly(vinyl chloride), Thermal Stability

\section{Introduction}

Hydrotalcite (called Layered Double Hydroxides, abbreviated as LDHs) is a kind of synthetic inorganic anionic laminar compound [1]. The interchangeable formula for the chemical composition of LDHs is: $\left[\mathrm{M}_{1-\mathrm{x}}{ }^{2+} \mathrm{M}_{\mathrm{x}}{ }^{3+}\right.$ $\left.(\mathrm{OH})_{2}\right]\left[\mathrm{A}^{\mathrm{n}-}\right]_{\mathrm{x} / \mathrm{n}} \cdot \mathrm{mH}_{2} \mathrm{O}$, where $\mathrm{M}^{2+}$ represents a kind of divalent metal cation, $\mathrm{A}^{\mathrm{n}-}$ represents a kind of interlayered n-valent inorganic (organic) anion [2] [3], and $\mathrm{M}^{3+}$ represents a kind of trivalent metal cation. The structure of LDHs is shown in Figure 1 [4]. Different kinds of ions can be intercalated into the layers of hydrotalcite

${ }^{*}$ Corresponding author.

How to cite this paper: Xue, X.Y., Zhang, S.H. and Zhang, H.M. (2015) Structures of LDHs Intercalated with Ammonia and the Thermal Stability for Poly(vinyl chloride). American Journal of Analytical Chemistry, 6, 334-341.

http://dx.doi.org/10.4236/ajac.2015.64032 


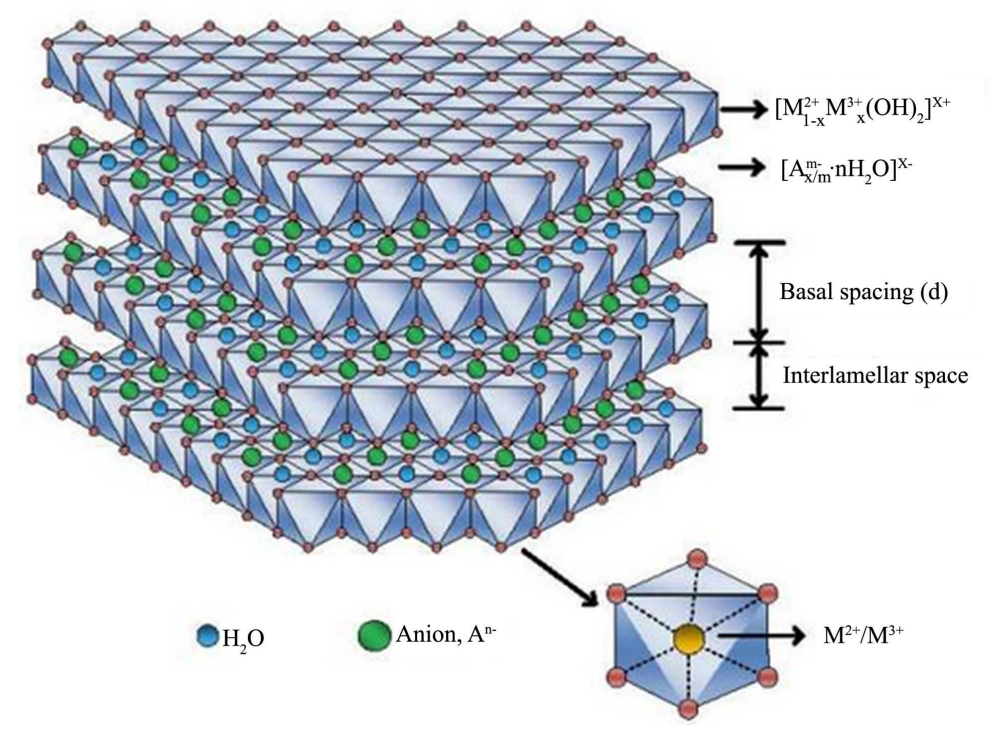

Figure 1. Structure of LDHs.

according to actual needs [5]. Due to the ion-exchange properties, adjustability of the laminates spacing, adjustability of LDHs, hydrotalcite has different selective adsorption properties and catalytic properties [6]. LDHs had to be modified so as to improve the thermal stability for PVC (Poly vinyl chloride).

In this research, MgAl-NH $\mathrm{NH}_{3} \mathrm{LDH}$, ZnAl-LDHs and $\mathrm{ZnAl}-\mathrm{NH}_{3} \mathrm{LDHs}$ with different molar ratio of Al/ammonia were synthesized by co-precipitation method. The synthetic LDHs samples were characterized by XRD, FTIR, TGA-DTG, and SEM techniques and tested by Congo red method. In addition, after PVC and DOP (Dioctylphthalate) were added to LDHs, the thermal stability for PVC was characterized by TGA-DTG.

\section{Experimental}

\subsection{Synthesis of LDHs}

All of the LDHs samples were synthesized by co-precipitation method [7].

MgAl-NH $\mathrm{LDHs}_{3}$ with different molar ratio $\left(\left[\mathrm{Mg}^{2+}\right] /\left[\mathrm{Al}^{3+}\right] /\left[\mathrm{NH}_{3} \cdot \mathrm{H}_{2} \mathrm{O}\right]=3: 1: 1,3: 1: 0.5,3: 1: 1.5,3: 1: 2\right)$ were prepared at $\mathrm{pH}=9-10$ under vigorous stirring. Acid solution containing $\mathrm{Mg}\left(\mathrm{NO}_{3}\right)_{2} \cdot 6 \mathrm{H}_{2} \mathrm{O}, \mathrm{Al}\left(\mathrm{NO}_{3}\right)_{3} \cdot 9 \mathrm{H}_{2} \mathrm{O}$ and $\mathrm{NH}_{3} \cdot \mathrm{H}_{2} \mathrm{O}$ and alkaline solution containing $\mathrm{NaOH}$ and $\mathrm{Na}_{2} \mathrm{CO}_{3}\left(\mathrm{CO}_{3}{ }^{2} / \mathrm{OH}^{-}=1.6\right)$ were added simultaneously to a three-necked round-bottom flask containing $50 \mathrm{~mL}$ deionized water. The reaction temperature was controlled at $90^{\circ} \mathrm{C}$, and stirring speed was controlled at $400 \mathrm{r} / \mathrm{min}$. The reaction solution was obtained under another $2-3$ hours after the acid and alkaline solution were dropped perfectly. Then the reaction solution were aged for 18 hours at $65^{\circ} \mathrm{C}$, filtered in vacuum to neutrality with de-ionized water and dried for 15 hours at $80^{\circ} \mathrm{C}$ in vacuum. Finally the samples obtained were ground, weighed and bagged.

Analogously, ZnAl-LDHs $\left(\left[\mathrm{Zn}^{2+}\right] /\left[\mathrm{Al}^{3+}\right]=2: 1\right)$ and $\mathrm{ZnAl}-\mathrm{NH}_{3}$ LDHs with different molar ratio $\left(\left[\mathrm{Zn}^{2+}\right] /\left[\mathrm{Al}^{3+}\right] /\right.$ $\left.\left[\mathrm{NH}_{3} \cdot \mathrm{H}_{2} \mathrm{O}\right]=2: 1: 1,2: 1: 0.5,2: 1: 1.5,2: 1: 2\right)$ were prepared by co-precipitation method. What was different were that the best molar ratio of $\mathrm{NaOH} / \mathrm{Na}_{2} \mathrm{CO}_{3}$ was 1.5 , the reaction temperature was controlled at $70^{\circ} \mathrm{C}$, the reaction solution were aged for 24 hours at $70^{\circ} \mathrm{Cand}$ dried for 18 hours at $75^{\circ} \mathrm{C}$.

\subsection{Characterization and Property Tests}

In the light of ISO 182/1-1990, Congo Red tests was applied to detect the thermal stability on LDHs for PVC. The mass ratio of PVC/DOP/LDHs was 100:5:5 and the oil bath temperature was kept at $190^{\circ} \mathrm{C}$ for at least 1 hour. The discoloration time of Congo Red dipstick required was the heat stabilizers time on LDHs for PVC.

$\mathrm{X}$-ray diffraction (XRD) results for LDHs samples were recorded using a PAN alytical X Per PRO diffractometer, $\mathrm{Cu} \mathrm{K} \alpha, 40 \mathrm{kV}, 4 \mathrm{~mA} .2 \theta$ value range from $5^{\circ}$ to $80^{\circ}$, and the rate was kept at $4^{\circ} \cdot \mathrm{min}^{-1}$.

Fourier Transform Infrared (FT-IR) spectrum was obtained with a Nicolet AVATAR 380 spectrometer, 400 $4000 \mathrm{~cm}^{-1}$ in air. The synthetic LDHs samples were mixed with $\mathrm{KBr}\left(0.200\right.$ g, p.a.) to form flake of $\mathrm{cm}^{-1}$. 
Scanning electron microscope (SEM) pictures were received by a S-3400N instrument produced by Japan's Hitachi corporation.

Thermal gravity analysis (TGA) and differential thermal gravity (DTG) curves for LDHs samples and PVC/ LDHs/DOP mixture were obtained with a SIINano TGA-DTG apparatus, $20^{\circ} \mathrm{C} \cdot \min ^{-1}, 20^{\circ} \mathrm{C}-800^{\circ} \mathrm{C}$, under nitrogen $\left(100 \mathrm{~mL} \cdot \mathrm{min}^{-1}\right)$.

\section{Results and Discussion}

\subsection{Congo Red Tests}

The Congo Red test results were shown in Table 1. Sample $2\left(\mathrm{Mg}^{2+}: \mathrm{Al}^{3+}: \mathrm{NH}_{3} \cdot \mathrm{H}_{2} \mathrm{O}=3: 1: 0.5\right)$ and Sample 8 $\left(\mathrm{Zn}^{2+}: \mathrm{Al}^{3+}: \mathrm{NH}_{3} \cdot \mathrm{H}_{2} \mathrm{O}=2: 1: 1.5\right)$ owned the best thermal stability time for PVC within the same series of LDHs samples. Thermal stabilization time of Sample 2, Sample 5, Sample 8 for PVC were respectively 43.0 min, 17.5 min, 41.0 min. In addition, thermal stabilization time of PVC/DOP without LDHs was 8.0 min. It was obvious that LDHs intercalated with ammonia improved the thermal stability time for PVC compared to non-intercalated LDHs. This was due to the effective reaction of ammonia with $\mathrm{HCl}$, which reduced the concentration of $\mathrm{HCl}$ and weakened the catalytic effect for PVC degradation. The reaction equation was as below:

$$
\mathrm{NH}_{4} \mathrm{OH}+\mathrm{HCl} \rightarrow \mathrm{NH}_{4} \mathrm{Cl}+\mathrm{H}_{2} \mathrm{O}
$$

Therefore, Sample $2\left(\mathrm{Mg}^{2+}: \mathrm{Al}^{3+}: \mathrm{NH}_{3} \cdot \mathrm{H}_{2} \mathrm{O}=3: 1: 0.5\right)$, Sample $5\left(\mathrm{Zn}^{2+}: \mathrm{Al}^{3+}=2: 1\right)$ and Sample $8\left(\mathrm{Zn}^{2+}: \mathrm{Al}^{3+}\right.$ : $\mathrm{NH}_{3} \cdot \mathrm{H}_{2} \mathrm{O}=2: 1: 1.5$ ) were characterized by XRD, FT-IR, TGA-DTG and SEM techniques in order to further study the structures of LDHs and the thermal stability for PVC.

\subsection{Powder X-Ray Diffraction}

As was shown in XRD (Figure 2) spectrum, the three samples all had characteristic diffraction peaks for LDHs. $\mathrm{D}$ (003) was relevant to the radius of anion in the intermediate layer and the interactions between anion and cation on the layers, where $d(003)$ represented the layer-layer spacing of the hydrotalcite-like compounds. If the charge density of anion was low, the interactions between anions and positively charged layers was weak, and then the layer spacing was large. $d(110)$ reflected the atomic arrangement density of the (110) crystal plane [8].

As was shown, Sample $5\left(\mathrm{Zn}^{2+}: \mathrm{Al}^{3+}=2: 1\right)$ and Sample $8\left(\mathrm{Zn}^{2+}: \mathrm{Al}^{3+}: \mathrm{NH}_{3} \cdot \mathrm{H}_{2} \mathrm{O}=2: 1: 1.5\right)$ had more obvious (015) and (018) crystal plane compared with Sample $2\left(\mathrm{Mg}^{2+}: \mathrm{Al}^{3+}: \mathrm{NH}_{3} \cdot \mathrm{H}_{2} \mathrm{O}=3: 1: 0.5\right)$. The diffraction peak intensity of Sample 8 was stronger than Sample 5 after intercalation with ammonia. According to $t=0.9 \lambda / \beta \cos \theta$, as $2 \theta$ value increased, the layer spacing of LDHs decreased [9]. It can clearly be seen that Sample $2\left(\mathrm{Mg}^{2+}\right.$ : $\left.\mathrm{Al}^{3+}: \mathrm{NH}_{3} \cdot \mathrm{H}_{2} \mathrm{O}=3: 1: 0.5\right)$ owned the biggest interlaminar distance.

\subsection{Infrared Spectroscopy}

As was shown in IR spectra (Figure 3), the effective intercalation of ammonia can also be confirmed. The broad

Table 1. Congo Red test results.

\begin{tabular}{ccc}
\hline Sample code & molar ratio for reactants & Stability time (min) \\
\hline 0 & $\mathrm{PVC} / \mathrm{DOP}$ without LDHs & 8.0 \\
1 & $\mathrm{Mg}^{2+}: \mathrm{Al}^{3+}: \mathrm{NH}_{3} \cdot \mathrm{H}_{2} \mathrm{O}=3: 1: 1$ & 30.0 \\
2 & $\mathrm{Mg}^{2+}: \mathrm{Al}^{3+}: \mathrm{NH}_{3} \cdot \mathrm{H}_{2} \mathrm{O}=3: 1: 0.5$ & 43.0 \\
3 & $\mathrm{Mg}^{2+}: \mathrm{Al}^{3+}: \mathrm{NH}_{3} \cdot \mathrm{H}_{2} \mathrm{O}=3: 1: 1.5$ & 39.0 \\
4 & $\mathrm{Mg}^{2+}: \mathrm{Al}^{3+}: \mathrm{NH}_{3} \cdot \mathrm{H}_{2} \mathrm{O}=3: 1: 2$ & 31.0 \\
5 & $\mathrm{Zn}^{2+}: \mathrm{Al}^{3+}=2: 1$ & 17.5 \\
7 & $\mathrm{Zn}^{2+}: \mathrm{Al}^{3+}: \mathrm{NH}_{3} \cdot \mathrm{H}_{2} \mathrm{O}=2: 1: 1$ & 35.0 \\
8 & $\mathrm{Zn}^{2+}: \mathrm{Al}^{3+}: \mathrm{NH}_{3} \cdot \mathrm{H}_{2} \mathrm{O}=2: 1: 0.5$ & 33.0 \\
9 & $\mathrm{Zn}^{2+}: \mathrm{Al}^{3+}: \mathrm{NH}_{3} \cdot \mathrm{H}_{2} \mathrm{O}=2: 1: 1.5$ & 41.0 \\
\hline
\end{tabular}




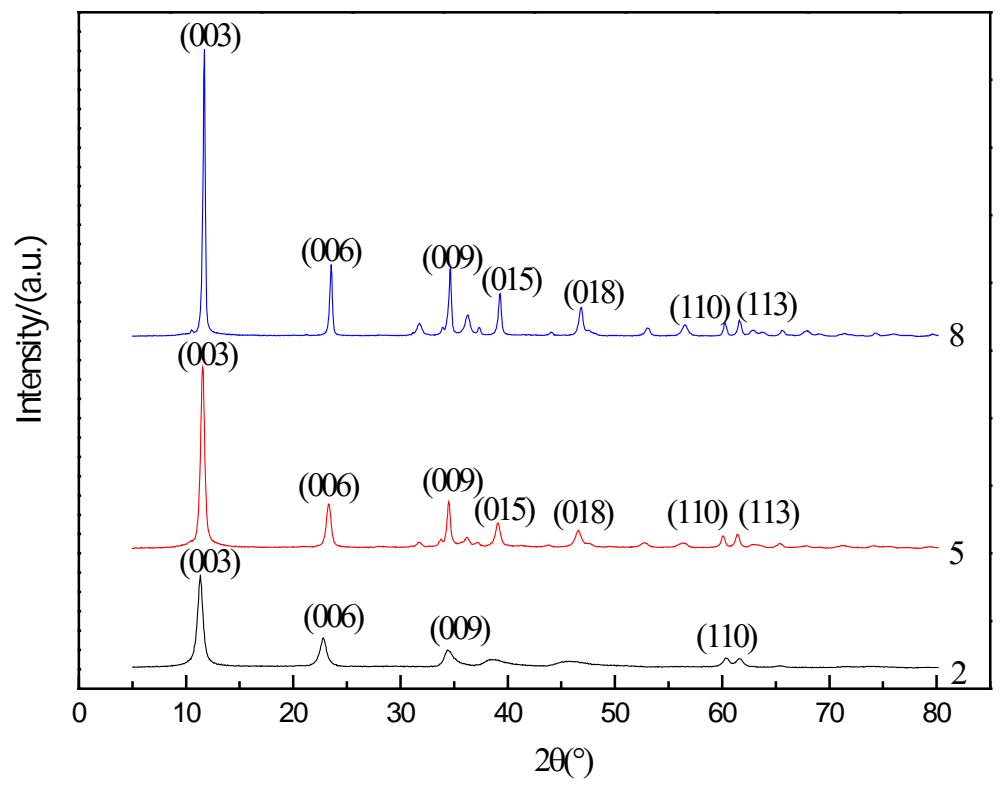

Figure 2. XRD spectrum. 2: MgAl-NH $\mathrm{N}_{3}$ LDHs; 5: ZnAl-LDHs; 8: ZnAl-NH LDHs.

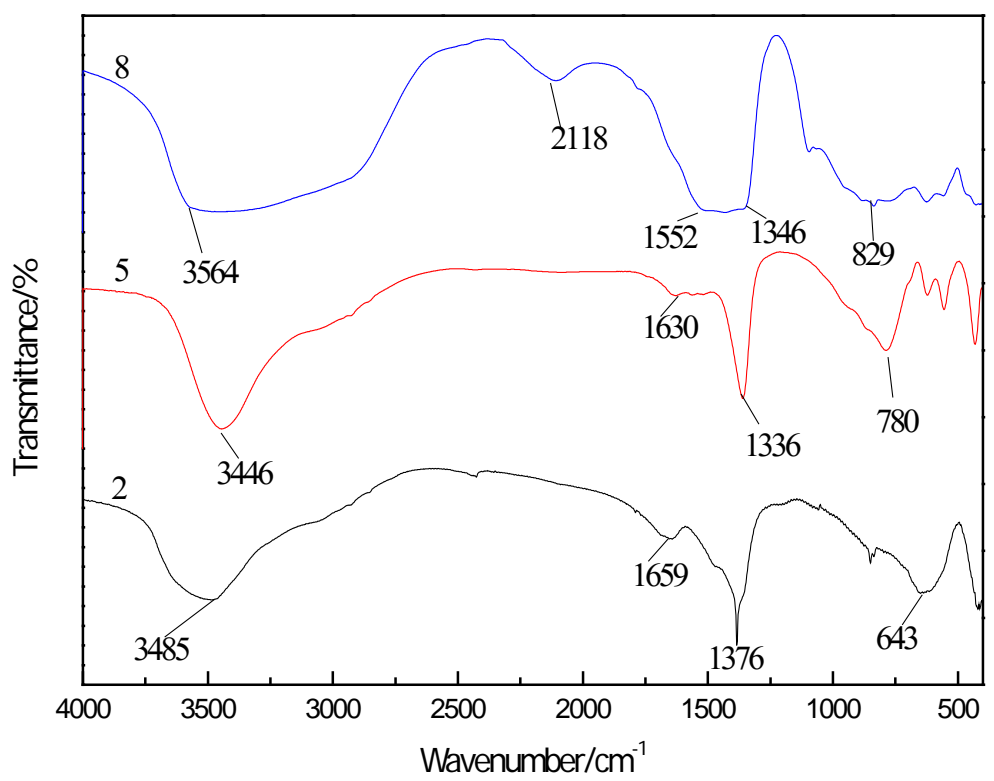

Figure 3. IR spectra. 2: MgAl-NH${ }_{3}$ LDHs; 5: ZnAl-LDHs; 8: $\mathrm{ZnAl-NH}$ LDHs.

band visibly appearing at $3430-3580 \mathrm{~cm}^{-1}$ may be due to $\mathrm{O}-\mathrm{H}$ groups of the intercalated $\mathrm{H}_{2} \mathrm{O}$ and stretching vibrations of $\mathrm{OH}^{-}$. The weak band appearing at about $1600 \mathrm{~cm}^{-1}$ is attributed to the bending mode of $\mathrm{H}_{2} \mathrm{O}$ molecules. Weak peak appearing at $2118 \mathrm{~cm}^{-1}$ in Sample $8\left(\mathrm{Zn}^{2+}: \mathrm{Al}^{3+}: \mathrm{NH}_{3} \cdot \mathrm{H}_{2} \mathrm{O}=2: 1: 1.5\right)$ is associated with the stretching vibration of $\mathrm{N}-\mathrm{H}$ bond. Compared with carbonate ion in free state (appearing at $1415 \mathrm{~cm}^{-1}$ ), the peak resulted from the asymmetric stretching vibration for C-O bond in $\mathrm{CO}_{3}^{2-}$ group of LDHs appeared at 1320 $1380 \mathrm{~cm}^{-1}$, significantly shifting to the lower wave number, which attests carbonate ion inserted between layers of LDHs are not really disengaged ions and have strongly interacted with interlaminar $\mathrm{H}_{2} \mathrm{O}$ molecules by hydrogen bonding. Other absorption peak appearing near $700 \mathrm{~cm}^{-1}$ are assigned to the bending and stretching vibration modes for metal-oxygen bonds [10]. 


\subsection{TGA and DTG Analysis}

As was shown in TGA and DTG curves (Figure 4 and Figure 5), there existed two weight loss stage.The first weight loss stage $\left(\mathrm{T}<250^{\circ} \mathrm{C}\right)$ corresponded to the release of crystal water between the layers and adsorbed water on the surface of LDHs samples. The second weight loss stage corresponded to the release of $\mathrm{CO}_{3}^{2-}$ in the form of $\mathrm{CO}_{2}$ between the layers, and during the second stage the reduced quality also included dehydration of most hydroxy group on the laminates. All the hydroxy group were removed at higher temperatures, and thus the laminate structure of LDHs samples were completely destroyed, generating mixed oxides finally [11] [12]. As was shown, when the temperature was below $300^{\circ} \mathrm{C}$, the weight loss for the three samples were different, and as temperature growed, Sample 5 showed the best thermal stability. Intercalating ammonia reduced the thermal stability for LDHs.

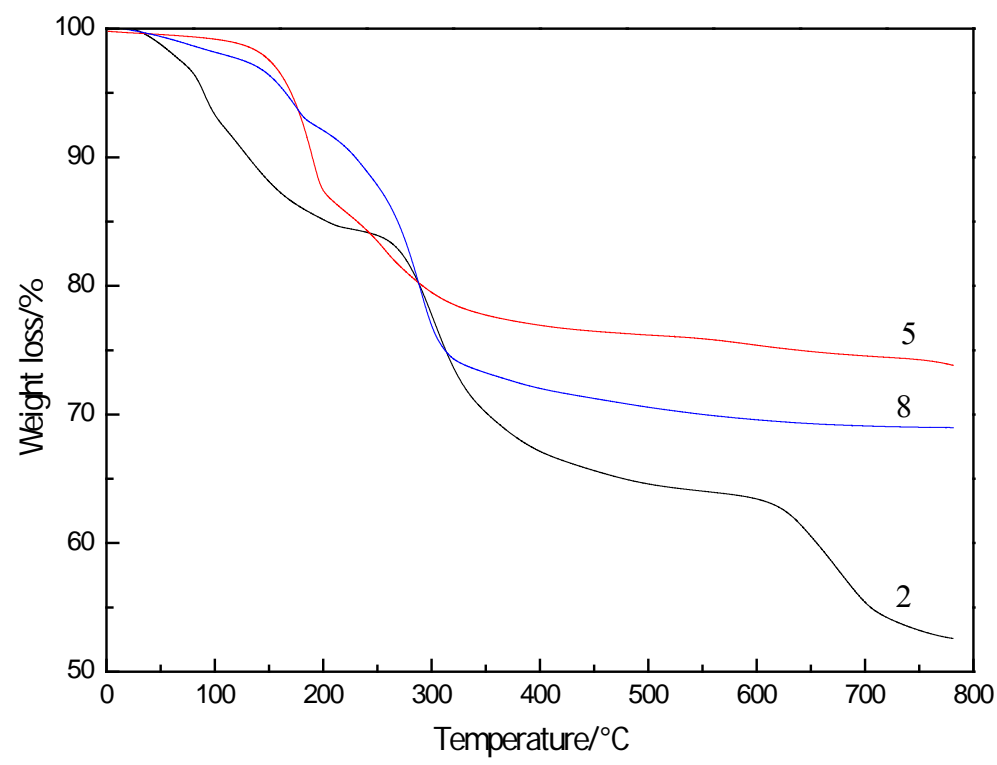

Figure 4. TGA curves for LDHs. 2: MgAl-NH ${ }_{3}$ LDHs; 5: ZnAl-LDHs; 8: $\mathrm{ZnAl}-\mathrm{NH}_{3} \mathrm{LDH}$.

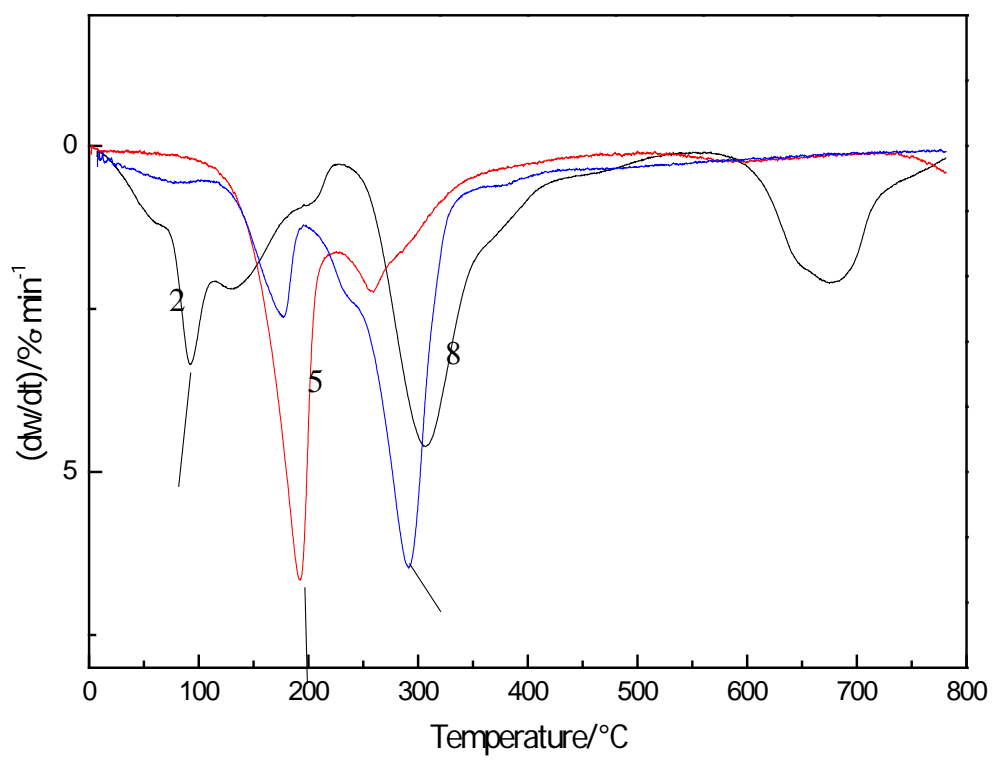

Figure 5. DTG curves for LDHs. 2: MgAl-NH $\mathrm{NH}_{3}$ LDs; 5: ZnAl-LDHs; 8: ZnAl-NH 3 LDHs. 


\subsection{SEM Analysis}

SEM pictures shown in Figure 6 exhibited the particle morphologies of all the three synthesized LDHs samples. Sample $2\left(\mathrm{Mg}^{2+}: \mathrm{Al}^{3+}: \mathrm{NH}_{3} \cdot \mathrm{H}_{2} \mathrm{O}=3: 1: 0.5\right)$, Sample $5\left(\mathrm{Zn}^{2+}: \mathrm{Al}^{3+}=2: 1\right)$ and Sample $8\left(\mathrm{Zn}^{2+}: \mathrm{Al}^{3+}: \mathrm{NH}_{3} \cdot \mathrm{H}_{2} \mathrm{O}=\right.$ 2:1:1.5) all exhibited the layered structures and the crystals dispersed on the surface of the particles, but the crystal sizes were different and tended to agglomerate into a big block. It can obviously be seen that intercalating ammonia had weaken the grain dispersion and the layer space became larger, the particle sizes became larger, the surface area became larger with the tendency to agglomerate. The SEM analysis further validated the effect of intercalated ammonia for the crystal structures of LDHs.

\subsection{The Thermal Stability for PVC}

TGA and DTG curves in $\mathrm{N}_{2}$ for LDHs/PVC/DOP were shown in Figure 7 and Figure 8. Compared with PVC/DOP, it was obvious that adding LDHs improved the thermal stability for PVC. TGA curves can be divided into two well-differentiated main regions. The first region (ranging from $100^{\circ} \mathrm{C}$ to $450^{\circ} \mathrm{C}$ ) was related to the formation of conjugated polyene sequences and the dehydrochlorination. Released $\mathrm{HCl}$ will speed up the degradation for PVC. $\mathrm{CO}_{3}^{2-}$ as well as the hydroxyl groups and other interlayer anions such as ammonia will be removed from the brucite-like layers of LDHs in this temperature range [13]. The second region (over $450^{\circ} \mathrm{C}$ ) attributed to formation of residual chars and decomposition of polyene backones.

\section{Conclusion}

Three kinds of LDHs samples all have typical diffraction peaks. Thermal stabilization time of $\mathrm{MgAl}-\mathrm{NH}_{3} \mathrm{LDHs}$,
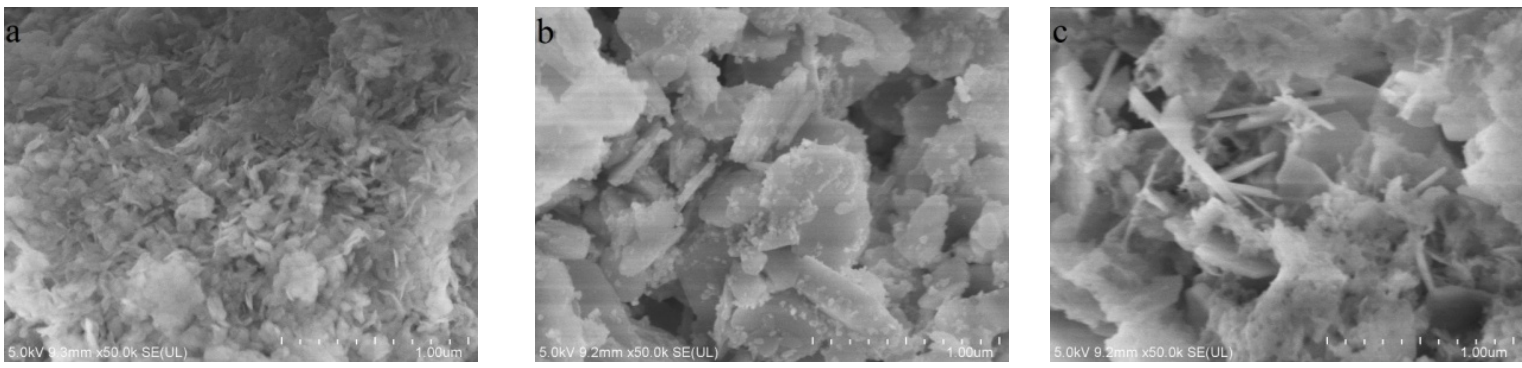

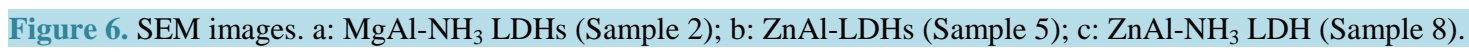

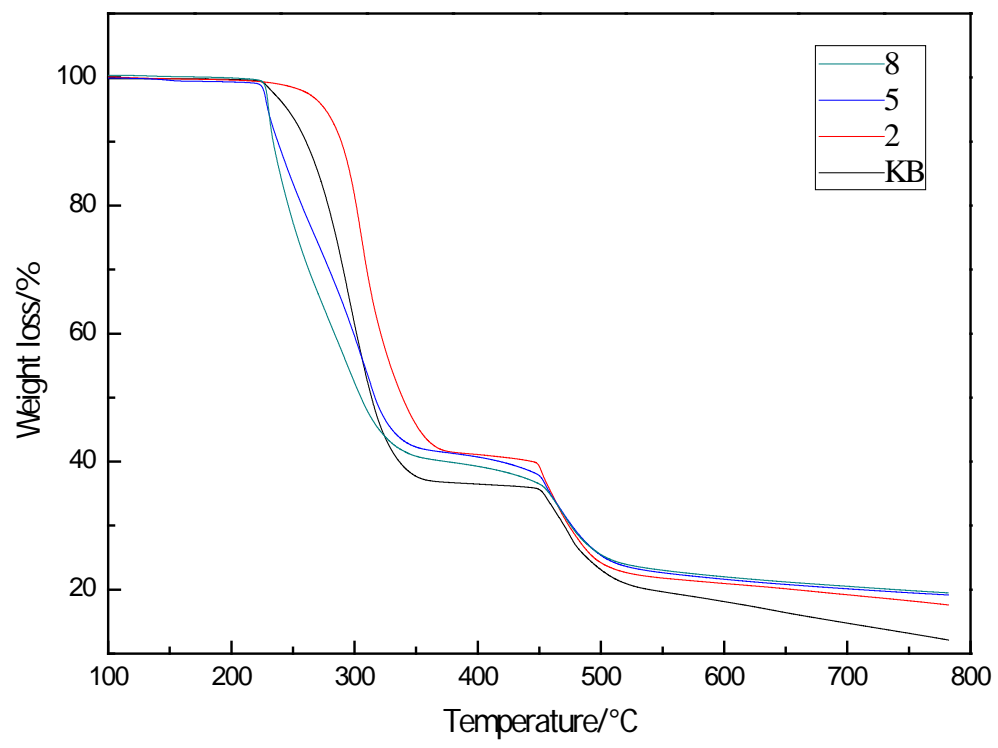

Figure 7. TGA curves for LDHs/PVC/DOP. KB: PVC/DOP; 2: PVC/DOP/

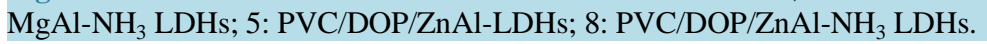




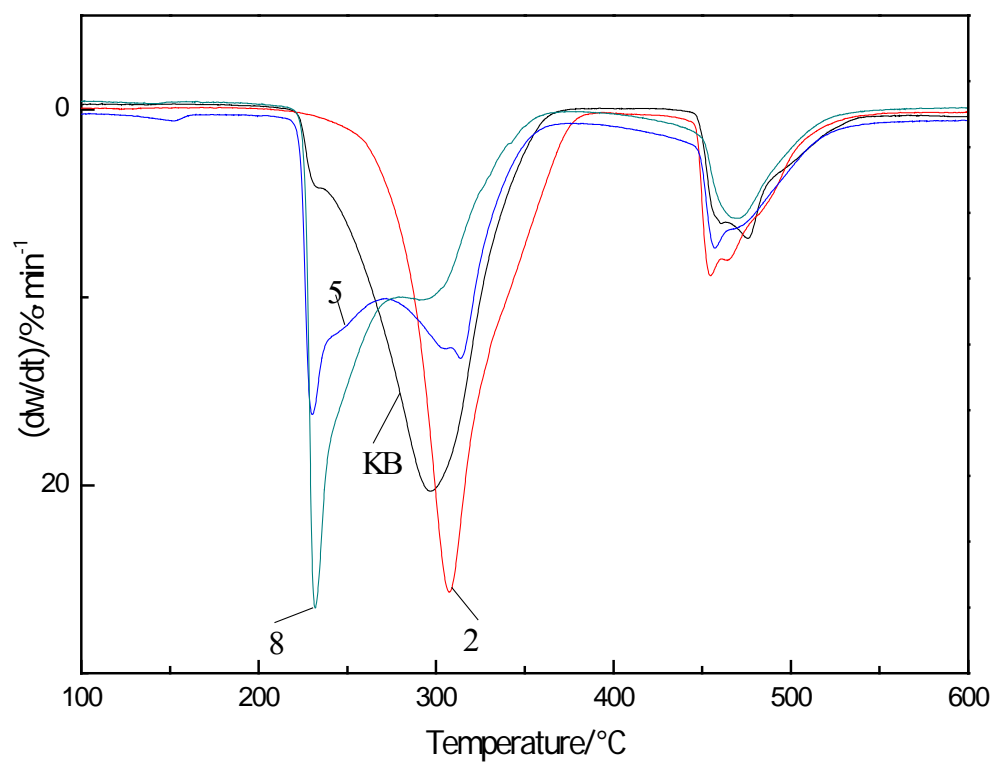

Figure 8. DTG curves for LDHs/PVC/DOP. KB: PVC/DOP; 2: PVC/DOP/ MgAl-NH $\mathrm{NH}_{3}$ LDF; 5: PVC/DOP/ZnAl-LDHs; 8: PVC/DOP/ZnAl-NH LDHs.

ZnAl-LDHs, ZnAl-NH $\mathrm{NH}_{3}$ LDHs for PVC were respectively $43.0 \mathrm{~min}, 17.5 \mathrm{~min}, 41.0 \mathrm{~min}$. LDHs intercalated with ammonia improved thermal stability for PVC significantly, MgAl-NH $\mathrm{NDHs}_{3}\left(\mathrm{Mg}^{2+}: \mathrm{Al}^{3+}: \mathrm{NH}_{3} \cdot \mathrm{H}_{2} \mathrm{O}=3: 1: 0.5\right)$ and $\mathrm{ZnAl}-\mathrm{NH}_{3}$ LDHs $\left(\mathrm{Zn}^{2+}: \mathrm{Al}^{3+}: \mathrm{NH}_{3} \cdot \mathrm{H}_{2} \mathrm{O}=2: 1: 1.5\right)$ showed the best thermal stability for PVC, interlayered space of LDHs became larger by intercalating ammonia.

\section{Acknowledgements}

We acknowledge the financial support received from Shanghai municipal education commission with "Twelfth Five" scientific connotation construction project (number: nhky-2012-05), Foreign visiting scholar fellowship program (B-8938-12-0406). The author gratefully thanks beamline 7.3.3 and 8.0.1 at Advanced Light Source of Lawrence Berkeley National Lab, supported by the Director of the Office of Science, Office of Basic Energy Sciences, of the US Department of Energy under Contract No. De-AC02-05CH11231.

\section{References}

[1] Xu, X.P., Chu, W., Wang, N., et al. (2011) Hydrogen Production by Ethanol Steam Reforming on NiCuMgAl Catalysts Derived from Hydrotalcite-Like Precursors. Catalysis Letters, 141, 1228-1236. http://dx.doi.org/10.1007/s10562-011-0608-0

[2] Nyambo, C., Chen, D., Su, S.P., et al. (2009) Does Organic Modification of Layered Double Hydroxides Improve the Fire Perform Ance of PMMA. Polymer Degradation and Stability, 94, 1298-1306. http://dx.doi.org/10.1016/j.polymdegradstab.2009.03.023

[3] Yang, Z.H. and Chi, W.W. (2008) Synthesis and Application of Mg-Al-Ca Ternary Hydrotalcite in PVC. Plastics Additives, 18-21.

[4] Li, K.R., Xiao, Q. and De, B. (2010) Synthesis, Characterization and Catalytic Properties for Acetone Condensation of Mg-Al Hydrotalcite. Molecular Catalysis, 309-314.

[5] Xu, X.P., Chu, W., Wang, N., et al. (2011) Hydrogen Production by Ethanol Steam Reforming on NiCuMgAl Catalysts Derived from Hydrotalcite-Like Precursors. Catalysis Letters, 141, 1228-1236. http://dx.doi.org/10.1007/s10562-011-0608-0

[6] Zhang, Z., Zhang, Y., Su, Q., et al. (2010) Determination of Intermediatesand Mechanism for Soot with NO/O ${ }_{2}$ on Potassium-Supported Mg-Al Hydrotalcitemixed Oxides by in Situ FTIR. Environmental Science \& Technology, 44, 82548258. http://dx.doi.org/10.1021/es102363f

[7] Ren, L.L., He, J. and Duan, X. (2001) Intercalation Assembled Anionic Pillared Materials. Chemical Bulletin, 64, 686- 
691.

[8] Zeng, H.Y., Wang, J., Feng, Z., You, K.Y., Zhao, C., Sun, J.W. and Liu, P.L. (2010) Synthesis of Propylene Glycol Monomethyl Ether Over Mg/Al Hydrotalcite Catalyst. Catalysis Letters, 137, 94-103. http://dx.doi.org/10.1007/s10562-010-0335-y

[9] Kannan, C.S.S. (1992) Synthesis and Physicochemical Characterization of Cobalt Aluminium Hydrotalcite. Journal of Materials Science Letters, 11, 1585-1587. http://dx.doi.org/10.1007/BF00740840

[10] Jindra, P. and Kim, F.D. (2005) New Insight into the Formation of Structural Defects in Poly(vinyl chloride). Marcromolecules, 38, 6352-6366. http://dx.doi.org/10.1021/ma050035p

[11] Chen, L.Q., Han, B. and Liu, Q. (2011) Synthesis and Characterization of Mg-Al and Mg-Zn-Al Hydrotalcite. Salt Industry, 43, 38-41.

[12] Roy, S. and Baiker, A. (2009) $\mathrm{NO}_{\mathrm{x}}$ Storage-Reduction Catalysis: From Mechanism and Materials Properties to Storage-Reduction Performance. Chemical Reviews, 109, 4054-4091. http://dx.doi.org/10.1021/cr800496f

[13] Yurco, M., Bagnasco, G., Costantino, U., Marmottini, F., Montanari, T., Ramis, G. and Busca, G. (2004) Production of Hydrogen from Oxidative Steam Reforming of Methanol I. Preparation and Characterization of $\mathrm{Cu} / \mathrm{ZnO} / \mathrm{Al}_{2} \mathrm{O}_{3} \mathrm{Cata-}$ lysts from a Hydrotalcite-Like LDH Precursor. Journal of Catalysis, 228, 43-55.

http://dx.doi.org/10.1016/S0021-9517(04)00412-9 